\title{
Analysis on the Legislation of Rural Drinking Water Management in Jiangxi Province
}

\author{
$\mathrm{Na}$ Yin \\ Law School \\ Nanchang Institute of Technology \\ Nanchang, China
}

\begin{abstract}
Rural drinking water safety is the core of ensuring and improving people's livelihood, which is closely related to the health and happiness of rural residents. As the most basic guarantee for people's livelihood, rural drinking water safety is helpful to implement the strategy of rural revitalization, win the battle to get rid of poverty, and jointly build and share beautiful homes. It is an urgent problem to solve the health damage caused by insufficient drinking water purification for a long time. At present, there is no legislation on drinking water management in rural areas, which makes the drinking water in rural areas not be properly protected. Based on the actual situation of Jiangxi Province, this paper analyzes the problems existing in rural drinking water management in Jiangxi Province, and puts forward that legislation is the only way to solve the problem. The safeguard means to solve the problem of drinking water safety in rural areas.
\end{abstract}

Keywords-rural drinking water; drinking water management; drinking water legislation

\section{INTRODUCTION}

Water is the source of all life and the material basis for human survival and development. Water has the dual attributes of natural resources and economic resources. The safety of drinking water is the basic demand of human survival and development. The safety of drinking water in the countryside is concerned with the stability of the rural society, the economic development and the physical and mental health of the rural residents. But there is no clear and unified definition of the "rural drinking water". The existing rural drinking water laws and regulations, from the national basic law to the local legislation, mostly use the concepts of "rural water supply", "rural drinking water safety" and so on. On the definition of rural drinking water safety, in 2012, the National Rural Drinking Water Safety Engineer The provision is made in the "12th Five-Year" "Rural drinking water safety means that rural residents can obtain sufficient and sufficient drinking water in a timely and convenient way." Plan, namely, that the safety of rural drinking water as defined herein generally includes four evaluation indicators, namely, water quality, water volume, water convenience level and water supply assurance rate. The "rural drinking water" generally refers to the use of water for rural areas under the cover of the urban centralized water supply network, and the rural domestic water includes the water for the residents, the water for washing, the water for livestock and poultry, etc.

From the analysis of the above related concepts, it can be seen that the concepts of "rural drinking water" and "rural drinking water safety" are not completely the same. "Rural drinking water safety" pays attention to the quality and quantity of drinking water, reflecting the natural and social attributes of water safety, while "rural drinking water" is determined from the scope, reflecting the delineation of the scope of rural drinking water safety management. However, with the development and change of modern rural society, the definition of the scope of "rural drinking water" is limited to "rural drinking water", which has certain parochialism. With the construction of new rural areas and the implementation of the national policy of accurate poverty alleviation, rural drinking water is no longer limited to life. The use of water should also include water for production and operation. Therefore, from the social point of view of rural drinking water management, rural drinking water refers to the use of village and town water supply projects to rural residents and units and other water users to supply domestic water and production and management of water activities.

\section{The Legislation AND Problems OF the RURAL DRINKING WATER MANAGEMENT}

\section{A. Legal Framework for Rural Drinking Water Management}

At present, China has not formulated a special law on rural drinking water. The existing laws on the protection and management of drinking water include a constitution, a number of laws, administrative regulations and many local rural water supply management methods. A constitution, that is, the Constitution of the people's Republic of China. Some laws, such as Water Law, soil and Water Conservation Law, Water pollution Prevention Law, Flood Control Law, Environmental Protection Law, etc; certain administrative regulations, such as River Management regulations, regulations on the Administration of Water intake permits and Collection of Water Resources fees, etc; measures for the management of rural water supply in many localities, such as Hebei Rural Water supply and Water supply Management measures, Lake Measures for the Management of drinking Water supply in Rural Pastoral areas of Inner 
Mongolia Autonomous region, measures for the Construction of Peasants' drinking Water Project outside the Urban Water supply Network of Ningbo City, measures for the Management of Rural Public Water supply in Shandong Province, regulations on Water supply in villages and towns of Sichuan Province, measures on Rural drinking Water Management in Wuhan City, measures on Rural Water supply Management in Zhejiang Province, etc.

\section{B. The Decentralization of the Rural Drinking Water Management}

In the light of the legislation of rural drinking water, our country has not set up a more centralized and unified national legislation specifically for rural drinking water, which is reflected in the comprehensive laws such as the Water Law and the Law on the Prevention and Control of Water Pollution. These laws are of high levels, but lack systematicness and operability. For example, the water method, although the content is more comprehensive, it is too principle; the Law on Water and Soil Conservation, the Law on the Prevention and Control of Water Pollution, the Law on the Prevention and Control of Water Pollution, and the Regulations on the Administration of the Regulation of the River, the Regulations on the Administration of the Collection of Water for Water and the Administration of Water Resources and other administrative regulations, The special legislation for special affairs, many of the rural drinking water management None of the matters were specifically addressed. Although the General Office of the State Council, the State Development and Reform Commission and the Ministry of Water Resources have formulated policies and regulations to make arrangements and arrangements for the management of rural drinking water, the policies of the General Office of the State Council are mainly aimed at the national work of drinking water relief and drinking water security.

The regulations on Sand Mining and Sand Mining in Jiangxi Province, the regulations on farmland Water Conservancy in Jiangxi Province, the regulations on Water Conservancy projects in Jiangxi Province and the regulations on Water Resources in Jiangxi Province have not been specifically related to many matters in the management of drinking water in rural areas. Although the "six-step method" for standardized management of water conservancy projects in Jiangxi Province has put forward basic requirements for engineering management, it is mainly aimed at dam, flood control and other water conservancy work, which can't cover the management needs of rural water supply projects. "measures for Sanitary Supervision and Management of centralized Water supply in Rural areas of Jiangxi Province" on unit production hygiene requirements, water quality inspection, hygiene supervision and monitoring of centralized water supply projects The requirements have been made, but no decentralized water supply works under thousands of thousands of people are involved; other normative documents are limited to a certain department or on one hand, and cannot solve the deep-level problems such as cross-cutting of functions. To this end, it is urgent to introduce the management system of the rural water supply in Jiangxi, standardize the management system in laws and regulations, and improve the management mechanism.

\section{PRESENT SitUATION OF RURAL DRINKING WATER MANAGEMENT IN JIANGXI PROVINCE}

\section{A. The Main Responsibility and Authority of Local Government for Ensuring Drinking Water Safety in Rural Areas Are Not Clear}

First, the local government does not pay enough attention to, the implementation of responsibilities is not in place. The rural drinking water safety project has not been paid attention to as a matter of livelihood, and the executive head responsibility system has not been implemented. Second, in the construction and operation management of the project, there are intersecting departments and multi-head management, and at the same time, there is a lack of management in some aspects, which affects the benign operation of the project. Third, the department communication is not in place. The water quality test results of some regional CDC did not copy the county (urban) government and its related departments and water supply responsible units in time, and even the law enforcement supervision departments at the same level did not know, and did not carry out supervision and law enforcement management in a timely and effective manner.

\section{B. The Rate of Reaching the Standard in the Construction of Single Village Project Is Not High}

Due to the distribution of unsafe population in rural areas, the small total number of unsafe drinking water population approved by the central government, the difficulty of raising funds and the difficulty of organizing and implementing the rural drinking water safety project, there are "equalitarianism" and "sprinkling pepper noodles" in the implementation of rural drinking water safety projects in various parts of our province. Some villages and towns allow small water supply projects to be constructed at will, and the construction standards are low, resulting in the construction of a large number of decentralized projects and single village projects. These small-scale water supply projects have become an obstacle to the subsequent construction of largescale water supply projects and the realization of the integrated development of urban and rural water supply. Secondly, due to the lack of legal basis, the supervision of self-provided water sources and water plants is not in place, and the water is not in place. The problems of disorderly development, repeated investment in engineering construction and high cost of water plant acquisition lead to the loss of national natural resources and funds. PVC pipe is mostly used in the early construction of engineering water supply network, and the aging phenomenon of pipe network is serious. Lack of water purification, disinfection facilities and testing equipment, water quality is difficult to meet the standards, can only solve the problem of convenient water use, it is difficult to fundamentally solve the problem of drinking water safety of rural residents. 
farmers and the weak willingness to pay. Fourth, the project management is simple, the management personnel lack of professional knowledge. The village water plant is generally appointed by the village committee or the farmers' water use association as the administrator. Due to low wages, a lot of chores, lack of professional management, maintenance and operation knowledge, only care and simple operation, so that the project in the operation of pipe leakage and other phenomena caused a big wave The cost of maintenance and maintenance will be increased and the operating cost will be increased.

\section{E. Water Price Mechanism Is Not Clear}

Jiangxi Province has different water charges in each water supply area, and the initial loading fee is not equal, which leads to the low enthusiasm of farmers to pay water fees. In addition, the thought of farmers drinking welfare water is widespread. Compared with urban residents, the consciousness of treating engineering water supply as commercial water has not yet formed, resulting in the collection of water charges is difficult to collect, or even can't be collected at all, resulting in a vicious circle of operation and management. There is a common problem of low daily water consumption of farmers in rural drinking water projects. If there is no basic water charge, it is difficult to ensure the daily operation cost of the project.

\section{LEGISLATIVE PATH OF RURAL DRINKING WATER MANAGEMENT IN JIANGXI PROVINCE}

\section{A. Guiding Ideology}

The most important thing in the legislation of rural drinking water management in our province is to change the traditional orientation of giving priority to economic value, and taking sustainable development as the guiding ideology of legislation in the new period is in line with the development needs of the times and based on the development needs of our province. At the same time, the basic idea and value orientation of rural drinking water management legislation in our province should take ensuring drinking water safety and environmental fairness and justice as the basic guiding ideology, coordinate urban and rural environmental protection, take legal measures to solve the problem of rural drinking water safety, and adhere to the guiding ideology of fairness and justice in drinking water source pollution. At present, farmers, as vulnerable groups in the environment, bear the ring of inequality with their rights. The problem of farmers' environmental rights is essentially a problem of social fairness and justice. From the perspective of environmental justice, paying attention to the fact that farmers bear the environmental obligations which are not equal to their enjoyment of rights reflects the status of vulnerable groups in farmers' environment. The concept of environmental justice and sustainable development is embedded in the legal norms to promote the sustainable development of human and natural environment and human society, and to gradually solve the problem of rural drinking water safety caused by the dual structure of urban and rural

areas in China. In the aspect of legal relief, the balance of
Because of the small scale of the water plant, the low level of rural economic development, the limited bearing capacity of 
Hebei, and the NPCSC will make a comprehensive system regulation on all aspects related to the protection and protection of drinking water in rural areas through the development of a uniform and applicable regulation of the whole province.

\section{The Path of Promoting the Legislation of Rural Drinking Water Management in our Province}

First, make clear the public welfare of rural water supply project, deal with the relationship between public welfare and management. The characterization of rural drinking water project is directly related to the solution of deep-seated problems in the construction and management of rural drinking water project, but there has been a lack of corresponding legal and policy basis at present. Rural drinking water project is an important infrastructure in rural areas, serving the vast number of farmers, the construction and operation costs are high, the efficiency is poor, requires a large amount of national investment, the operation of the project basically has policy losses, can't operate according to the laws of the market. Not for the purpose of profit, the audience is very wide, the nature of public welfare is very obvious. In order to determine the public welfare nature of rural drinking water in law, it is to carry out the construction capital of the project. Gold, land, electricity, tax and maintenance, water price subsidies, water quality testing and other related preferential policies.

Second, clear the local government rural drinking water safety guarantee main responsibility, water conservancy, ecological environment, health and other departments specific responsibilities. In the process of rural drinking water project construction and management, the relevant government departments at all levels in Jiangxi Province have the problem of unclear division of functions. According to the guidance of the Ministry of Water Resources on further strengthening the Operation and Management of Rural drinking Water Safety projects (Water Farmers (2015) 306): the departments in charge of water administration shall be responsible for the construction and operation guidance, management and supervision of rural drinking water safety projects, development and reform, finance, health and family planning, environmental protection, urban and rural construction, etc. Objective construction, project operation management and protection related policies, financial security and water quality monitoring, water source protection and other work. "Clear division of responsibilities among various departments, strengthen departmental cooperation.

The competent department of water administration shall be responsible for the construction and management of rural drinking water projects in its own administrative area; the competent department of ecological environment shall be responsible for the delineation of drinking water source protected areas and the prevention and control of pollution; the competent department of health and health shall be responsible for carrying out hygienic evaluation and water quality monitoring; and other relevant competent departments shall, within the scope of their respective duties, drinking water management legislation in our province can draw on the provincial practice of Shandong, Zhejiang and 
perform the duties of supervision and management related to rural drinking water.

Through the implementation of the main responsibility of the local government, to ensure project construction funds and project operation and maintenance funds. It is a longterm task to ensure the safety of drinking water in rural areas, and it has the characteristics of obvious stage, dynamics, repetition, complexity and difficulty. Due to the long-term existence of urban-rural dual structure, rural water supply infrastructure has been relatively weak for a long time. At present, there are still some outstanding problems in rural drinking water project, such as small water supply scale, low water supply guarantee rate, incomplete water purification facilities, high pipe network leakage rate, low household admission rate and low qualified rate of water quality, etc. The engineering foundation to ensure drinking water safety is not strong enough, and the water quality guarantee capacity is not solid enough. The mechanism of management and operation and maintenance is not perfect, the policy and system guarantee measures are not enough to be implemented, the overall level of rural water supply is still quite different from that of urban water supply, and it is not suitable for the integration of urban and rural development and the requirement of building a well-off society in an allround way. Through the implementation of the main responsibility of the local government, the local government should take the initiative to take the initiative to include the funds needed for rural drinking water in the annual budget, so as to ensure the construction funds and the operation and maintenance funds of the project.

Fourth, we should encourage counties and districts to set up rural drinking water management institutions and strengthen the construction and management of rural drinking water projects in counties. The Ministry of Water Resources, the Office of the Central Organization Establishment Committee and the three departments of the Ministry of Finance have recently issued the guiding opinions on further perfecting the Grass-roots Water Conservancy Service system, implementing the 2011 Central document No. 1 and the spirit of the Central Water Conservancy work Conference, and speeding up the improvement of the grass-roots water conservancy service system. Therefore, the establishment of rural drinking water management institutions in this province has been carried out to improve the management level of rural drinking water projects. Rural drinking water management institutions mainly undertake the following public welfare functions: undertake the construction, management and transportation of rural water supply projects Carry out technical guidance for maintenance, organize and guide the construction and operation of farmers' water use cooperative organizations, organize and carry out publicity on drinking water safety and hygiene, etc. The rural drinking water management organization may carry out the management system which is mainly based on township management and the higher water administrative department carries on the business guidance, or it can also act as the dispatched office of the county level water administrative department, which shall be determined by the provincial people's government in accordance with the local conditions.

Fifth, establish a multi-channel fund-raising mechanism to encourage social funds to invest in engineering construction and management. The total demand of maintenance and maintenance funds for rural water supply projects in Jiangxi Province is high, and the current financial burden capacity is insufficient. In addition, the reasonable water price formation mechanism, engineering maintenance and maintenance fund and other long-term mechanisms are not perfect, so it is difficult to ensure the needs of engineering maintenance and maintenance. The shortage of funds for the construction and maintenance of rural drinking water projects is huge, and attracting social funds to invest in agricultural drinking projects can make up for the gap of funds to a certain extent.

Sixth, it is clear that the water price mechanism is clear, and it is put forward that for the areas where the water fee income is lower than the project operation cost and the maintenance and maintenance problems are more prominent, two water prices (basic water price measurement water price) should be carried out to ensure the daily operation and maintenance funds of the project. In the Circular on strengthening the Construction and Operation and Management of Rural drinking Water Safety projects, the National Development and Reform Commission, the Ministry of Health and the Ministry of Water Resources stipulate that the rural drinking water safety projects shall carry out paid water supply, measure charges, and gradually implement two water prices where conditions are in place. Reasonable water price policy is not only conducive to promoting the benign operation of rural water supply projects, but also conducive to regulating the water demand of farmers and promoting rural areas. Sustainable economic and social development. On the one hand, the two-part water price can make the operator get a stable income, which can be used for the overhaul and renovation of water supply facilities. The fixed cost of water supply can be compensated; on the other hand, according to the measured water price, the basic cost of operation is guaranteed. Multi-use and multidelivery promote the social benefits of engineering facilities. Reasonable water price will promote the rural drinking water safety project to be well managed and can be used to achieve the goal.

\section{CONCLUSION}

The legislation of rural drinking water management is related to the right of farmers to a better and happy life, and is the guarantee of the rule of law for the human rights of rural residents. Only by speeding up rural legislation can we provide a beautiful living environment for rural residents. At present, there is no basic law of rural drinking water management in our country, which brings many challenges to rural drinking water management. In view of the problems in the practice of rural drinking water management in Jiangxi Province, speeding up the legislation of rural drinking water management in Jiangxi Province is the key to solve many problems at present. This paper probes into the guiding ideology and legislative mode of drinking water management 
legislation in Jiangxi Province, and probes into the path of rural drinking water management legislation in Jiangxi Province. Management legislation provides policy guidance.

\section{REFERENCES}

[1] Gao Lihong, Zhou Yongfei: an Analysis of the legal guarantee of drinking Water Safety in Rural areas of China. No. 6, 2015.

[2] Deng Xiaoyun:Basic Theory Differentiation of Agricultural Source Pollution, Journal of Henan Normal University(Philosophy and Social Science Edition)Issue 6, 2013.

[3] Liu Zhenhua. Study on the necessity of legislation on safe drinking Water in Rural areas. China Rural Water Conservancy and Hydropower. No. 14, 2011.

[4] Xiao Yan: on drinking Water Safety in Rural areas. Water Administration and Water Resources 2018 No. 2.

[5] Zhang Shuo, Lin Jinwen, Chen Jinmu. "experience and Enlightenment of Local Rural drinking Water Safety legislation." Water Conservancy Development Research, No. 9, 2015.

[6] Cai Shouqiu et al., Sustainable Development and legal Construction of Environmental Resources, China legal Publishing House, 2003, p. 418. 